\title{
Analgesic, anti-inflammatory and antipyretic activities of ethanolic extract of stem bark of Anogeissus latifolia Roxb
}

Vikas Chandra Sharma ${ }^{1,2^{*}}$, Atul Kaushik2 ${ }^{2}$, Yadu Nandan Dey ${ }^{3,4}$, Bhavana Srivastava ${ }^{4}$, Manish Wanjari ${ }^{4}$ and Bhagat Jaiswal ${ }^{5}$

\begin{abstract}
Background: Stem bark of Anogeissus latifolia Roxb (family: Combretaceae) is used traditionally and ethnomedicinally to alleviate pain, inflammation and fever conditions. The current study investigates the analgesic, anti-inflammatory and antipyretic activities of ethanolic extract of stem bark of Anogeissus latifolia Roxb.

Method: The HPLC studies were carried out to standardize the stem bark ethanolic extract of Anogeissus latifolia (ALEE) using ellagic acid as a marker. ALEE was screened for analgesic (formalin-induced pain and acetic acid induced writhing) and anti-inflammatory (formalin and carrageenan-induced paw oedema) activities in Wistar rats. Before $1 \mathrm{~h}$ of acetic acid or formalin or carrageenan injection, rats were orally fed with ALEE (100, 200 and $400 \mathrm{mg} /$ $\mathrm{kg})$, Aspirin $(100 \mathrm{mg} / \mathrm{kg})$ or Indomethacin $(10 \mathrm{mg} / \mathrm{kg})$. Antipyretic effect was studied in brewer's yeast-induced pyrexia model in rats using Paracetamol $(100 \mathrm{mg} / \mathrm{kg})$ as a standard drug.
\end{abstract}

Results: HPLC analysis of ALEE revealed the presence of ellagic acid. ALEE treatment (200 and $400 \mathrm{mg} / \mathrm{kg}$ ) significantly inhibited pain response in both models. ALEE treatments prevented the raise of paw volume in both in-vivo models with percent inhibition of 44.40 and 46.21 , respectively at $5 \mathrm{~h}$. ALEE also showed a significant reduction of yeast-induced pyrexia till $4 \mathrm{~h}$ of treatment.

Conclusion: ALEE exhibited analgesic, anti-inflammatory and antipyretic property in experimental models and validates traditional use of ALEE in pain, inflammation and fever.

Keywords: Dhau, HPLC, Anogeissus latifolia, Inflammation, Fever, Ellagic acid

\section{Background}

The medicinal plants or their formulations are widely used in traditionally practices by different ethnic population worldwide for the prevention and/or treatments of several chronic diseases. In spite of development of newer technologies and advancement in modern medicine, a high proportion of world population still relies on traditional systems of medicine to fulfill their medical

\footnotetext{
* Correspondence: vikas.a.sharma08@gmail.com

'Department of Pharmaceutical Sciences, IFTM University, Moradabad 244001, Uttar Pradesh, India

${ }^{2}$ IPS College of Pharmacy, Gwalior 474001, Madhya Pradesh, India Full list of author information is available at the end of the article
}

care [1]. The public interest in herbal is increasing exponentially day by day.

Inflammation is a defensive response protecting against the injured tissue caused by various stimuli such as heat, chemicals, and immunological reactions. Generally it is associated with dolorous condition of pain and hyperthermia and needs timely pharmacological treatment [2]. Though current treatment includes NSAIDs (Nonsteroidal anti-inflammatory drugs) for relieving painful conditions, inflammation as well as fever but their unrestricted use poses several side effects such as ulcers, hemorrhage [3], liver and kidney toxicities [4]. Hence, there is an inclination towards the herbal drugs for alleviation of pain and inflammation. In Ayurvedic 
system of medicine, plant based medicine are widely as Vedana shamak or shothhar [5]. Thus, there is increasing interest of peoples in the validation of traditional medicinal plants in India and other countries for treatment of inflammatory conditions.

Anogeissus latifolia Roxb (Family: Combretaceae is a large to moderate sized tree which is common throughout Nepal, Myanmar, Sri Lanka and India in deciduous forests of the Himalayas and South Indian Hills [6]. It is commonly called 'Dhau' widely used in traditional medicinal system of India. The stem bark is used in Ayurvedic practices for treating Asmari (calculus), Arsa (piles), Mutrakrcchra (dysuria), Karnasrava (otorrhoea), Medoroga (obesity), Kustha (leprosy/ diseases of skin), Prameha (metabolic disorder), Pandu (anaemia), Upadamsa (syphilis/ soft chancre), Raktavikara (disorders of blood) and Visarpa (erysepales) [7]. In the ethnomedicinal practices, the various plant parts are consumed for the correction of painful conditions like back pain and inflammatory conditions [8-13]. Stem bark is also used in ethnomedicinal practices for the correction of cough and common cold $[14,15]$. Stem bark mainly contains tannin, $(+)$ leucocyanidin and ellagic acid [16], glucoside ester [17], $\beta$-sistosterol, hydroxy acetytaraxaren [18] and gallotannin and $\beta$-penta-O-galloylated glucose [16].

In view of the traditional and ethnomedicinal use of stem bark of Anogeissus latifolia in inflammatory and dolorous conditions, it was thought worthwhile to study its analgesic, inflammatory and antipyretic effect in the different models of pain, inflammation and fever in Wistar rats, respectively.

\section{Method}

\section{Drugs and chemicals}

Ellagic acid (percent purity $>$ 95\%) was purchased from Cayman Chemical Company Michigan, USA. Carrageenan was procured from Sigma-Aldrich, USA while Brewer's yeast was procured from M.P. Biomedicals, USA. Aspirin, indomethacin and paracetamol were obtained as gift sample from M/S Royal Research Center, Navsari, Gujarat, India. During the experimental study all analytical grade solvent, chemicals and reagents used in the research work.

\section{Collection and authentication of plant material}

Stem barks of Anogeissus latifolia Roxb (AL) were collected in the month of September, 2015 from Ghatigaon forest of Gwalior District, Madhya Pradesh, India and authenticated by the Chief Botanist (Mr. N. K. Pandey), Regional Ayurveda Research Institute for Drug Development, Gwalior, India. Voucher specimen submitted in the herbarium of the Institute for future (no. 5-4/ 10-11/NRIASHRD/Tech/Survey/1516).

\section{Preparation of ALEE}

Plant material was dried in dark at $25-32{ }^{\circ} \mathrm{C}$. The shade dried plant material was subsequently ground to powder (coarse) and passed through 60 no sieves. The dried plant material was treated with $95 \%$ ethanol for extraction in soxhlet assembly. The extract was concentrated in a rotary evaporator to obtain ALEE with $14.01 \%$ w/w percent yield.

\section{Preliminary phytochemical screening}

Phytochemical screening of ALEE was screened by the well establish standard methods [19]. The quantitative estimation of total phenolic and flavonoids were done by the previously described method [20].

\section{High performance liquid chromatography (HPLC) analysis of ALEE}

HPLC analysis of ALEE was carried out at Royal Research Center, Navsari, Gujarat, India. The HPLC system (Shimadzu Corporation, Japan model no. LC-2010A) comprised of Enable C-18G HPLC column (particle size$250 \times 4.6 \mathrm{~mm}$ size and $5 \mu \mathrm{m}$ inner diameter). The photodiode array detector and class-VP software were available in the system. Samples (ellagic acid and ALEE at 0.1 and $50 \mathrm{mg} / \mathrm{ml}$, respectively) were eluted in mobile phase [acetonitrile (A) and water (B) in gradient elution mode (A: B) $95: 5(0-2 \mathrm{~min})$ to $90: 10(2-5 \mathrm{~min}), 80: 20(5-15$ $\mathrm{min}), 75: 25(15-20 \mathrm{~min})$ and $95: 5(20-27.5 \mathrm{~min})]$. The other chromatographic conditions consisted of wave length $(254 \mathrm{~nm})$, flow rate $(0.5 \mathrm{ml} / \mathrm{min})$, and injection volume $(5-15 \mu \mathrm{l})$ [21]. The percentage of ellagic acid was estimated by the using the areas obtained in the chromatograms of ALEE and standard.

\section{Experimental animals}

Healthy adult male Wistar rats (200-250 g) were procured from Defense Research \& Development Establishment (DRDE), DRDE Gwalior, India and housed in polypropylene cages with autoclaved husk bedding in a group of 2-3 animals/ cage. They were fed standard rodent chow (Ashirwad brand, Chandigarh, India) and water ad libitum and were housed at IPS College of Pharmacy, Gwalior, Madhya Pradesh (Registration: $1039 \mathrm{PO} / \mathrm{Re} / \mathrm{S} / 07 / \mathrm{CPCSEA})$ at housing temperature: $25 \pm 2{ }^{\circ} \mathrm{C}$; humidity: $50 \pm 5 \%$ and light-dark (1:1) cycle. All experimental protocols were performed during day time day (10 AM to $5 \mathrm{PM}$ ) after approved (proposal no. 1783/2015) by Institutional Animal Ethics Committee. The sample size (n) was determined by a power analysis (power $>0.80 ; \mathrm{a}=0.05$, two tailed). The calculated sample size was 5 per group. 


\section{Acute toxicity study}

Acute toxicity of ALEE was carried out by the following OECD 423 guidelines [22] and methods described previously $[23,24]$. The orally administration of ALEE with limit test dose of $2000 \mathrm{mg} / \mathrm{kg}$ was done in overnight fasted rats (sample size $=3$ ) and observed for 14 days for any death or toxic signs.

\section{Assessment of analgesic activity \\ Writhing test}

The analgesic effect of ALEE was screened using acetic acid-induced writhing test [25]. Intraperitoneal injection of acetic acid $(10 \mathrm{ml} / \mathrm{kg}, 0.6 \%)$ in rats caused writhings (stretch, torsion to one side, retraction of the abdomen and opisthotonous so that the belly of the rodent touches to the floor) which are counted. Total 25 rats were randomly divided into 5 groups each containing 5 rats. Rats were pretreated with vehicle (4\% gum acacia) or ALEE $(100,200$ and $400 \mathrm{mg} / \mathrm{kg})$ or aspirin $(100 \mathrm{mg} /$ $\mathrm{kg}) 1 \mathrm{~h}$ before acetic acid administration and thereafter the observations were made. The number of writhing was counted for $30 \mathrm{~min}$. Aspirin $(100 \mathrm{mg} / \mathrm{kg}$, orally) was as reference standard. The analgesic activity was estimated by the formula given below.

$$
\text { Percentage inhibition }=\frac{(\mathrm{Nc}-\mathrm{Nt})}{\mathrm{Nc}} \times 100
$$

Where, Nc is mean number stretchings in control $\mathrm{Nt}$ is mean number stretchings in test.

\section{Formalin-induced pain}

ALEE was screened for inflammatory pain evaluated by formalin-induced pain model in rats [26] with some modifications. Total 25 rats were randomly divided into 5 groups each containing 5 rats. After $1 \mathrm{~h}$ orally pretreated rats with vehicle (4\% gum acacia) or ALEE (100, 200 and $400 \mathrm{mg} / \mathrm{kg})$ or indomethacin $(10 \mathrm{mg} / \mathrm{kg})$ intraperitoneal administration of $0.05 \mathrm{ml}$ of $2.5 \%$ commercially available $37 \%$ formalin in dorsal surface of left hind paw in rats. Time of licking was recorded for 30 min followed by formalin administration. The early phase $(10 \mathrm{~min})$ and late phase $(10$ and $30 \mathrm{~min})$ which represents neurogenic and inflammatory pain response, respectively. Analgesic activity (\% Inhibition) at early and late phase was calculated by the following formula.

$$
\text { Percentage inhibition }=\frac{\mathrm{Nc}-\mathrm{Nt}}{\mathrm{Nc}} \times 100
$$

Where, Nc is average licking (sec) in control,
$\mathrm{Nt}$ is the average licking $(\mathrm{sec})$ in test

\section{Assessment of anti-inflammatory activity Carrageenan-induced paw oedema}

The anti-inflammatory activity of ALEE was assessed in rats using carageenan-induced paw oedema model as per the previously described method [27]. Carrageenan suspension $(0.1 \mathrm{ml}$ of $1 \% \mathrm{w} / \mathrm{v}$ in normal saline) was injected into the sub-plantar region of right hind paw. Total 25 rats were randomly divided into 5 groups each containing 5 rats. Rats were pretreated with vehicle or ALEE $(100,200$ and $400 \mathrm{mg} / \mathrm{kg}$, orally) or reference standard indomethacin $(10 / \mathrm{mg} / \mathrm{kg})$ at $1 \mathrm{~h}$ earlier to carrageenan injection. The paw volume at $0,1,3$, and $5 \mathrm{~h}$ after carageenan administration was measured in $\mathrm{ml}$ using Plethysmometer (Ugo Basile, Italy. The antiinflammatory activity (\% Inhibition) was calculated by following formula.

$$
\text { Percentage inhibition }=\frac{(\mathrm{Pt}-\mathrm{P} 0) \text { control- }(\mathrm{Pt}-\mathrm{P} 0) \text { treated }}{(\mathrm{Pt}-\mathrm{P} 0) \text { control }} \times 100
$$

Where, $\mathrm{Pt}=$ Paw volume after carrageenan

administration

$\mathrm{P} 0=$ Paw volume before carrageenan administration

\section{Formalin-induced inflammation}

The animals previously studied for pain were further assessed for measuring inflammatory response [28]. Total 25 rats were randomly divided into 5 groups each containing 5 rats. Similar treatments and evaluation parameters were opted in this model as above and the percent inhibition of anti-inflammatory activity was calculated.

\section{Antipyretic activity}

The antipyretic activity was assessed by using Brewer's yeast-induced pyrexia model in rats [29]. Before inducing pyrexia, initial rectal temperature was recorded using a digital thermometer. Pyrexia was induced by subcutaneously injecting $15 \%$ Brewer's yeast $(10 \mathrm{ml} / \mathrm{kg}$ body weight) in $0.5 \% \mathrm{w} / \mathrm{v}$ in distilled water. After $18 \mathrm{~h}$ of yeast injection, the rats having increased temperature of more than $0.5^{\circ} \mathrm{C}$ were selected and further 25 rats were randomly divided into 5 groups each containing 5 . Control group received $15 \%$ oral suspension of yeast in distilled water. Paracetamol $(100 \mathrm{mg} / \mathrm{kg}$, orally) was used as a reference standard drug in the study while ALEE was fed orally at 100,200 and $400 \mathrm{mg} / \mathrm{kg}$. The rectal temperature was noted at $0,1,2,3$, and $4 \mathrm{~h}$ for all groups. 


\section{Statistical analysis}

All data were analyzed by one-way ANOVA followed Dunnet's multiple comparision post hoc tests or two way ANOVA followed by Bonferroni post hoc test, wherever applicable using prism pads software. A value of $P<0.05$ was taken significance in all cases.

\section{Results}

\section{Preliminary phytochemical screening}

Phytochemical tests revealed the occurrence of carbohydrates, phenols, saponins, alkaloids, steroids, flavonoids, quinones, furanoids and triterpenoids. The estimated total phenolic content was and flavonoid content were $62.86 \mathrm{mg}$ gallic acid equivalent and $40.64 \mathrm{mg}$ quercetin equivalent per gram ALEE, respectively.

\section{HPLC analysis}

HPLC analysis estimated ellagic acid in ALEE. The peaks represented by standard ellagic acid and ALEE were represented in Fig. 1 (A and B, respectively). The percentage of ellagic acid in ALEE was estimated as $0.38 \% \mathrm{w} / \mathrm{w}$. There was a linear relation observed between the peak area verses concentration of ellagic acid over the concentration range of $5-15 \mu \mathrm{g} / \mathrm{ml}$ with the regression coefficient $\left(r^{2}\right)$ of 0.999 . The recovery rates were higher than 99\% indicating high accuracy. The intra-day and interday RSD were 1.17 and 1.20, respectively indicating high precision or repeatability of the method. The calculated LOD and LOQ of ellagic acid were 0.38 and $0.5 \mu \mathrm{g} / \mathrm{ml}$, respectively. The validation parameters are mentioned in Table S1-S4 (Supplementary material).

\section{Acute toxicity of ALEE}

Acute toxicity study at limit oral dose $2000 \mathrm{mg} / \mathrm{kg}$ revealed normal behavioral and exhibited no death or lethargy and no signs of toxic effects in any behavioral patterns up to 14 days. The $\mathrm{LD}_{50}$ of ALEE is greater than $2000 \mathrm{mg} / \mathrm{kg}$, orally, and it seems safe and non-toxic.

\section{Analgesic activity \\ Effect on acetic acid-induced writhing}

ANOVA (One way) followed showed that ALEE exhibited a significant change on writhing test (Table 1). Post hoc test showed that ALEE caused significant inhibition of number of writhing at the dose of at 200 and $400 \mathrm{mg} / \mathrm{kg} \quad(P<0.05-P<0.001)$. The maximum inhibition exhibited at $400 \mathrm{mg} / \mathrm{kg}(66.83 \%)$. The effects were comparable to that of standard drug aspirin that also showed significant inhibition $(71.34 \%)$ of writhing $(P<0.01)$ (Table 1$)$.

\section{Effects on formalin induced pain response}

Effect on early and late phase licking One-way ANOVA showed that ALEE showed significant influence on formalin-induced licking of animals. Post hoc test indicated that pretreatment with ALEE (200 and $400 \mathrm{mg}$ / $\mathrm{kg})$ showed significant $(P<0.05-P<0.001)$ inhibition of the early phase and late phase licking when compared to vehicle control (Table 2). Indomethacin at $10 \mathrm{mg} / \mathrm{kg}$ also also showed similar effect on early phase licking $(P<$ $0.001)$ as well as the late phase licking $(P<0.01)$ when compared to vehicle control.
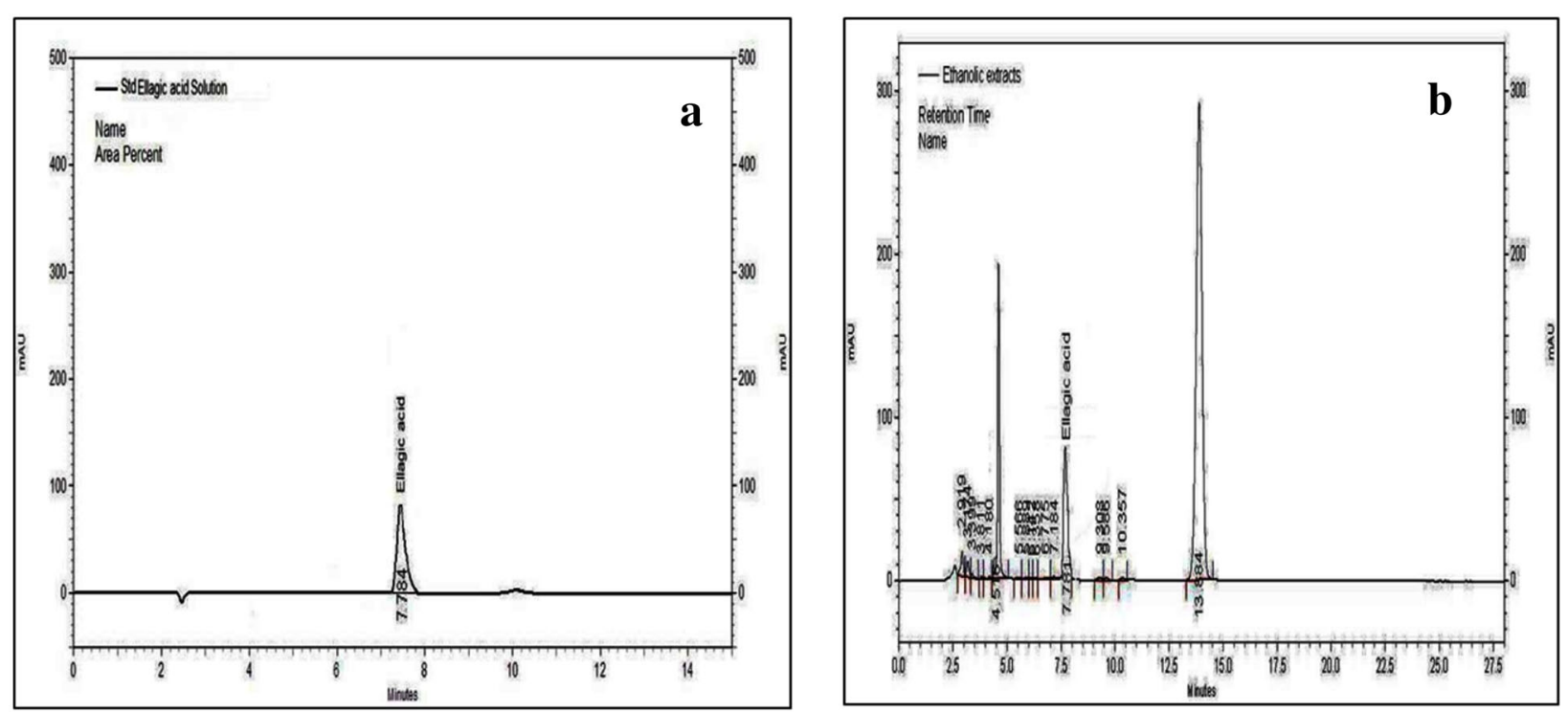

Fig. 1 a HPLC Chromatogram of ALEE. a Ellagic acid (b) Ethanolic extract of stem bark of Anogeissus latifolia (ALEE) 
Table 1 Analgesic effect of ALEE on acetic acid-induced writhing in rats

\begin{tabular}{llll}
\hline Treatments & Dose $(\mathrm{mg} / \mathrm{kg})$ & Number of writhing & Percentage Inhibition (\%) \\
\hline Control & - & $64.67 \pm 3.19$ & - \\
ALEE & 100 & $60.26 \pm 2.26$ & 6.82 \\
& 200 & $54.68 \pm 1.87^{*}$ & 15.44 \\
& 400 & $21.45 \pm 1.12^{* *}$ & 66.83 \\
Aspirin & 100 & $18.53 \pm 1.16^{* *}$ & 71.34
\end{tabular}

Results are expressed as mean \pm SEM $(n=5)$. ${ }^{*} P<0.05 ;{ }^{*} P<0.001$ compared to Control. ALEE: Ethanolic extract of stem bark of $A$. latifolia

\section{Anti-inflammatory activity}

Carrageenan-induced paw oedema Two-way ANOVA showed significant influence of ALEE on carrageenaninduced inflammation (Table 3). Bonferroni post hoc tests indicated ALEE showed time and dose dependent inhibition of paw oedema. ALEE $(200 \mathrm{mg} / \mathrm{kg})$ showed time dependent inhibition $(P<0.05$ and $P<0.001$ at $3 \mathrm{~h}$ and $5 \mathrm{~h}$ ) of the mean raise in paw volume compared with vehicle control rats. The high dose of ALEE (400 $\mathrm{mg} / \mathrm{kg})$ showed significant $[(P<0.01(3 \mathrm{~h})$ and $P<0.001$ $(5 \mathrm{~h})$ ] inhibition of the mean increase in paw volume (oedema) in time dependent manner as indicated by increased percent inhibition of paw oedema compared to control rats. Standard drug indomethacin also exhibited similar effect $(P<0.001)$ from $3 \mathrm{~h}$ onward. The prominent anti-inflammatory activity was noted at $5 \mathrm{~h}$ after carrageenan injection. ALEE at 100, 200 and $400 \mathrm{mg} / \mathrm{kg}$ exhibited percent inhibition of paw oedema 7.66, 39.78 and $44.40 \%$, respectively whereas indomethacin showed significant percent inhibition of $59.48 \%$ at $5 \mathrm{~h}$ (Table 3 ).

\section{Formalin-induced paw oedema}

Two-way ANOVA showed significant influence of ALEE on formalin-induced inflammation (Table 4). Bonferroni post hoc tests indicated ALEE showed time and dose dependent inhibition in paw volume. ALEE treatment $(200 \mathrm{mg} / \mathrm{kg})$ showed inhibition in paw oedema at 3 and $5 \mathrm{~h}(P<0.05$ and $P<0.001$, respectively), while ALEE $(400 \mathrm{mg} / \mathrm{kg})$ exhibited significant inhibitory effect $(P<$ 0.001 ) only at 3 and $5 \mathrm{~h}$. The percentage inhibition of inflammation exhibited by ALEE (100, 200 and $400 \mathrm{mg} / \mathrm{kg}$ ) was $12.32,37.25$ and $46.21 \%$ at $5 \mathrm{~h}$ while that of indomethacin was $59.94 \%$ (Table 4).

\section{Antipyretic activity}

In antipyretic study, two-way ANOVA showed significant influence of ALEE on yeast-induced pyrexia (Table 5). ALEE (100, 200 and $400 \mathrm{mg} / \mathrm{kg}$ ) as well as paracetamol significantly reduced hyperthermia in rats in time dependent manner. ALEE (200 and $400 \mathrm{mg} / \mathrm{kg}$ ) exhibited a significant change $(P<0.05$ to $P<0.001)$ in hyperthermia from $3 \mathrm{~h}$ onwards (Table 5) when comparision made with control. The standard drug paracetamol also showed inhibition $(P<0.01$ to $P<0.001)$ of fever from $2 \mathrm{~h}$ as compared to control.

\section{Discussion}

The current study clearly indicates the analgesic, antiinflammatory and antipyretic potential of ALEE in animal models.

HPLC study of ALEE reveals the occurrence of ellagic acid, an important phytoconstituent of Anogeissus latifolia (Fig. 1a and b) in the concentration range of $0.38 \%$ w/w.

Acute toxicity suggests that ALEE was safe when administered orally at limit test dose of $2000 \mathrm{mg} / \mathrm{kg}$. The results of the analgesic activity suggest that ALEE exhibited significant inhibition of pain response in both chemically-induced pain models. The effect of ALLE was comparable to aspirin in amelioration of acetic acidinduced pain in rats which suggest the role of ALEE in inhibition of cyclooxygenase or lipoxygenase pathway

Table 2 Analgesic activity of ALEE on formalin-induced paw licking test rats

\begin{tabular}{|c|c|c|c|c|c|}
\hline \multirow[t]{2}{*}{ Treatments } & \multirow{2}{*}{$\begin{array}{l}\text { Dose } \\
\text { (mg/ } \\
\mathrm{kg})\end{array}$} & \multicolumn{2}{|l|}{ Licking time (sec) } & \multicolumn{2}{|l|}{ Inhibition (\%) } \\
\hline & & Early Phase (0-10 min) & Late Phase (10-30 min) & Early Phase (0-10 min) & Late Phase (10-30 min) \\
\hline Control & - & $78.6 \pm 1.34$ & $108.12 \pm 3.41$ & - & - \\
\hline \multirow[t]{3}{*}{ ALEE } & 100 & $72.39 \pm 2.46$ & $101.20 \pm 1.59$ & 7.90 & 6.40 \\
\hline & 200 & $68.38 \pm 1.61^{* *}$ & $95.12 \pm 3.56^{*}$ & 13.0 & 12.02 \\
\hline & 400 & $34.13 \pm 0.86^{* * *}$ & $21.35 \pm 2.17^{* * *}$ & 56.57 & 80.25 \\
\hline Indomethacin & 10 & $63.18 \pm 2.43^{* * *}$ & $18.65 \pm 1.13^{* * *}$ & 19.61 & 82.75 \\
\hline
\end{tabular}

Results are expressed as mean $\pm \operatorname{SEM}(n=5)$. ${ }^{*} P<0.05,{ }^{* *} P<0.01,{ }^{* * *} P<0.001$ compared to control 
Table 3 Anti-inflammatory effect of ALEE on carrageenan-induced rat paw oedema

\begin{tabular}{|c|c|c|c|c|c|}
\hline \multirow[t]{2}{*}{ Treatments } & \multirow{2}{*}{$\begin{array}{l}\text { Dose } \\
\text { (mg/kg) }\end{array}$} & \multicolumn{3}{|c|}{ Mean increase in paw volume $(\mathrm{ml})$} & \multirow{2}{*}{$\begin{array}{l}\% \\
\text { Inhibition } \\
\text { at } 5 \mathrm{~h}\end{array}$} \\
\hline & & $1 \mathrm{~h}$ & $3 \mathrm{~h}$ & $5 \mathrm{~h}$ & \\
\hline Control & - & $0.282 \pm 0.008$ & $0.620 \pm 0.017$ & $0.822 \pm 0.044$ & - \\
\hline \multirow[t]{3}{*}{ ALEE } & 100 & $0.263 \pm 0.029$ & $0.589 \pm 0.021$ & $0.759 \pm 0.025$ & 7.66 \\
\hline & 200 & $0.257 \pm 0.055$ & $0.467 \pm 0.044^{*}$ & $0.495 \pm 0.037^{* * *}$ & 39.78 \\
\hline & 400 & $0.223 \pm 0.033$ & $0.440 \pm 0.053^{* *}$ & $0.457 \pm 0.071^{* * *}$ & 44.40 \\
\hline Indomethacin & 10 & $0.215 \pm 0.036$ & $0.335 \pm 0.040^{* * *}$ & $0.333 \pm 0.050^{* * *}$ & 59.48 \\
\hline
\end{tabular}

Results are expressed as mean $\pm \operatorname{SEM}(n=5) .{ }^{*} P<0.05 ;{ }^{*} P<0.01 ;{ }^{* * *} P<0.001$ compared to Control. ALEE: Ethanolic extract of stem bark of $A$. latifolia

which is the general pathway of common peripherally acting analgesic drugs [30].

Formalin paw licking test produces a distinct biphasic response. Early phase is characterized by neurogenic pain (non-inflammatory) which which is generated by the activation of nociceptors [31] and involves substance $\mathrm{P}$ and bradykinin. The formalin-induced pain model also describes the inflammatory pain in the later phase [32, 33]. The peripheral inflammation may be induced due to the production of prostaglandins, serotonin and histamine [34]. Hence, this biphasic model is used extensively used to differentiate the exact mechanism of analgesics [35]. In present study, ALEE inhibited both early and late phase paw licking due to formalin. This suggests that ALEE has inhibitory influence on both neurogenic and inflammatory pain.

ALEE showed significant inhibition of carrageenan and formalin induced inflammation in dose dependent manner. In carrageenan-induced paw oedema model the early phase is not influenced of inhibited by NSAIDs and occurs due to the release of inflammatory mediators like histamine, serotonin and bradykinin while the late phase is marked by elevated production prostaglandins and induction of cyclooxygenase [36]. Late phase is accelerating phase of swelling due to increased vascular permeability and oedema caused by prostaglandins and can be inhibited by NSAIDs [37]. In the present study, treatment with ALEE and indomethacin showed significant inhibition of increase in paw volume at 3 and $5 \mathrm{~h}$ of carrageenan administration without influencing paw volume at $1 \mathrm{~h}$. This further confirms the anti-inflammatory action of ALEE. The exact mechanism of anti-inflammatory action of ALEE is difficult to interoperate, however, it can be contemplated that ALEE has influence on arachidonic acid pathway and inflammatory mediators like prostaglandins mainly by inhibiting COX enzyme as like indomethacin.

Formalin-induced induction of pain is known to be caused due to the inflammation of peripheral tissue [35]. Acute inflammatory response is mediated primarily by blood leukocytes such as neutrophils and macrophages [38]. Neutrophils stimulation also causes increased vascular permeability and produce oedema [39]. In formalin induced paw oedema model, results showed that subplantar injection of formalin caused significant increase in paw volume as compared to normal rat paw. Administration of ALEE significantly prevented the raise of paw oedema after formalin injection. Indomethacin also inhibited the paw volume increment at 3 and $5 \mathrm{~h}$ after formalin injection. Thus, it indicated the anti-inflammatory nature of the extract. Recently, Agnihotri et al. [40] demonstrated antioxidant and anti-inflammatory potential of Anogeissus latifolia stem bark on vascular and capillary permeability and inflammatory mediators and supports the present findings.

The etiology of yeast-induced fever which is considered as pathogenic fever suggests the role of prostaglandins in the thermoregulation of body temperature. The prostaglandin $\left(\mathrm{PGE}_{2}\right)$ during the arachidonic acid is

Table 4 Anti-inflammatory effect of ALEE on formalin-induced rat paw oedema

\begin{tabular}{|c|c|c|c|c|c|}
\hline \multirow[t]{2}{*}{ Treatments } & \multirow{2}{*}{$\begin{array}{l}\text { Dose } \\
(\mathrm{mg} / \mathrm{kg})\end{array}$} & \multicolumn{3}{|c|}{ Mean increase in paw volume (ml) } & \multirow{2}{*}{$\begin{array}{l}\% \\
\text { Inhibition } \\
\text { after } 5 \mathrm{~h}\end{array}$} \\
\hline & & $1 \mathrm{~h}$ & $3 \mathrm{~h}$ & $5 \mathrm{~h}$ & \\
\hline Control & - & $0.276 \pm 0.005$ & $0.634 \pm 0.011$ & $0.714 \pm 0.055$ & - \\
\hline \multirow[t]{3}{*}{ ALEE } & 100 & $0.261 \pm 0.012$ & $0.586 \pm 0.021$ & $0.626 \pm 0.032$ & 12.32 \\
\hline & 200 & $0.249 \pm 0.013$ & $0.528 \pm 0.065^{*}$ & $0.448 \pm 0.037^{* * *}$ & 37.25 \\
\hline & 400 & $0.232 \pm 0.002$ & $0.469 \pm 0.008^{* * *}$ & $0.384 \pm 0.022^{* * *}$ & 46.21 \\
\hline Indomethacin & 10 & $0.227 \pm 0.029$ & $0.324 \pm 0.003^{* * *}$ & $0.286 \pm 0.039^{* * *}$ & 59.94 \\
\hline
\end{tabular}

Results are expressed as mean $\pm \operatorname{SEM}(n=5) .{ }^{*} P<0.05 ;{ }^{* * *} P<0.001$ compared to control. ALEE: Ethanolic extract of stem bark of $A$. latifolia 
Table 5 Antipyretic effect of ALEE

\begin{tabular}{|c|c|c|c|c|c|c|}
\hline \multirow[t]{2}{*}{ Treatment } & \multirow{2}{*}{$\begin{array}{l}\text { Dose } \\
\text { (mg/kg) }\end{array}$} & \multicolumn{5}{|c|}{ Rectal temperature $\left({ }^{\circ} \mathrm{F}\right)$} \\
\hline & & $\mathrm{Oh}$ & $1 \mathrm{~h}$ & $2 \mathrm{~h}$ & $3 \mathrm{~h}$ & $4 \mathrm{~h}$ \\
\hline Control & - & $98.58 \pm 0.18$ & $101.41 \pm 0.24$ & $101.54 \pm 0.46$ & $101.76 \pm 0.21$ & $101.48 \pm 0.19$ \\
\hline \multirow[t]{3}{*}{ ALEE } & 100 & $98.80 \pm 0.41$ & $101.45 \pm 0.25$ & $101.31 \pm 0.49$ & $101.05 \pm 0.32$ & $100.35 \pm 0.43$ \\
\hline & 200 & $98.98 \pm 0.56$ & $101.44 \pm 0.41$ & $101.66 \pm 0.56$ & $100.10 \pm 0.46^{*}$ & $99.70 \pm 0.30^{* *}$ \\
\hline & 400 & $98.81 \pm 0.21$ & $101.48 \pm 0.32$ & $100.19 \pm 0.25$ & $99.97 \pm 0.56^{* *}$ & $99.29 \pm 0.38^{* * *}$ \\
\hline Paracetamol & 100 & $98.20 \pm 0.31$ & $101.80 \pm 0.52$ & $99.45 \pm 0.27^{* *}$ & $98.39 \pm 0.61^{* * *}$ & $98.78 \pm 0.38^{* * *}$ \\
\hline
\end{tabular}

Results are expressed as mean \pm SEM $(n=5) .{ }^{*} P<0.05 ;{ }^{* *} P<0.01 ;{ }^{* * *} P<0.001$ compared to control. ALEE: Ethanolic extract of stem bark of $A$. latifolia

considered an important factor for induction of fever $[41,42]$. The results of the current study yeast-induced fever model indicates the antipyretic activity of ALEE (Table 5) and its effect was comparable to paracetamol. Hence, it can be contemplated that the possible mechanism of antipyretic action of ALEE may be due to the inhibition of prostaglandin synthesis [35]. Most of NSAIDs suppress inflammation-associated hyperthermia [43] through inhibition prostaglandins synthesis [44]. Since, ALEE manifested antipyretic activity which may be related to its anti-inflammatory action.

It is quite difficult to conclude the exact constituent which may be accountable for the observed analgesic, antiinflammatory and antipyretic action of ALEE. ALEE contains ellagic acid as main polyphenolic chief constituent. Ellagic acid possesses good anti-inflammatory property in carrageenan-induced paw oedema model [45]. HPLC analysis has also quantified the fair amount of ellagic acid in ALEE which may be responsible for amelioration of inflammation. The quantitative estimation of phytoconstituents revealed the high content of phenolic and flavonoids in ALEE. The stem bark is also reported to have phytoconstituents like quercetin, rutin [46], tannin, $(+)$ leucocyanidin [16], glucoside ester [17], $\beta$-sistosterol, hydroxy acetytaraxaren and gallotannin and $\beta$-penta-O-galloylated glucose [18]. The phytoconstituents like quercetin [47], rutin [48] and $\beta$ sistosterol [49] were reported to have anti-inflammatory activity and might be responsible for the biological activities of ALEE in the present study. The results were in concordance with the previous study [50]. Thus, the analgesic and anti-inflammatory may be exhibited by the presence of phenolics and flavonoids in ALEE. The study needs further confirmation using estimation of markers of inflammation like COX and interleukins.

\section{Conclusion}

In conclusion, the ALEE exhibited analgesic, antiinflammatory and antipyretic effects. The presence of phenolic and flavonoid compounds which may be responsible for the effects. The study validates the use of stem bark of Anogeissus latifolia for treatment of painful inflammatory conditions.

\section{Supplementary information}

Supplementary information accompanies this paper at https://doi.org/10. 1186/s40816-020-00171-2.

\section{Additional file 1.}

\section{Abbreviations}

ANOVA: Analysis of Variance; COX: Cycloygenase; ${ }^{\circ} \mathrm{C}$ : Degree centegrate; FTIR: Fourier Transform Infrared Spectroscopy; g: gram; h: hour; HPLC: High performance liquid chromatography; kg: kilogram; ml: millimeter; NSAIDs: Nonsteroidal anti-inflammatory drugs; NMR: Nuclear Magnetic Resonance; ppm: parts per million; Rf: Refraction factor

\section{Acknowledgements}

Authors acknowledge the Royal Research Lab Pvt. Ltd., Navsari, Gujarat, India, to carry out HPLC studies and Dr. Vilas Shelar, Dr. Ashutosh Patidar and Dr. Kamal Goyal of Royal Research Lab Pvt. Ltd., Navsari, Gujarat, India, for providing guidance to the to carry out spectral analysis.

\section{Authors' contributions}

VCS prepared the plant extracts and executed the phytochemical studies. VCS and YD carried out the pharmacological studies. YD, VCS, AK, BS and MW designed the experiments. VCS, YD, MW and BS executed statistical analysis. AK, BS and MW made substantial contributions to drafting and revising the manuscript for intellectual content. All authors have read and approved the manuscript.

Funding

There was no financial assistance received for the study.

\section{Availability of data and materials}

All the data is contained in the manuscript.

\section{Ethics approval and consent to participate}

All experimental protocols were performed after approved (proposal no. 1783/2015) by Institutional Animal Ethics Committee. The consent to participate is not applicable.

\section{Consent for publication}

Not applicable.

\section{Competing interests}

The authors declare that they have no competing interests.

\section{Author details}

'Department of Pharmaceutical Sciences, IFTM University, Moradabad 244001, Uttar Pradesh, India. ${ }^{2}$ IPS College of Pharmacy, Gwalior 474001, Madhya Pradesh, India. ${ }^{3}$ School of Pharmaceutical Technology, Adamas University, Barasat, Kolkata 700126, West Bengal, India. ${ }^{4}$ Regional Ayurveda Research Institute for Drug Development, Gwalior 474009, Madhya Pradesh, India. ${ }^{5}$ Jiwaji University, Gwalior 474011, Madhya Pradesh, India. 
Received: 8 August 2019 Accepted: 6 April 2020 Published online: 17 April 2020

\section{References}

1. Politi FA, de Mello JC, Migliato KF, Nepomuceno AL, Moreira RR, Pietro RC. Antimicrobial, cytotoxic and antioxidant activities and determination of the total tannin content of bark extracts Endopleura uchi. Int J Mol Sci. 2011;12: 2757-68.

2. Hossain H, Al-Mansur A, Akter S, Sara U, Ahmed MR, Jahangir AA. Evaluation of anti-inflammatory activity and total tannin content from the leaves of Bacopa monnieri (Linn.). Int J Pharm Sci Res. 2014:5:1246-52.

3. Hajhashemi V, Sajjadi SE, Heshmati M. Anti-inflammatory and analgesic properties of Heracleum persicum essential oil and hydroalcoholic extract in animal models. J Ethnopharmacol. 2009;124:475-80.

4. Pannu N, Nadim MK. An overview of drug-induced acute kidney injury. Crit Care Med. 2008;36:S216-23.

5. Mishra LC. Rheumatoid arthritis, osteoarthritis and gout. Scientific Basis for Ayurvedic Therapies. Boca Raton: CRC Press; 2004.

6. Chopra RN, Nayar SL, Chopra IC, Asolkar LV, Kakkar KK. Glossary of Indian medicinal plants. New Delhi: Council of Scientific and Industrial Research; 1956

7. Anonymous. The Ayurvedic Pharmacopoeia of India, Government of India Ministry of Health \& Family Welfare Department of Ayush, 1st Edition Part Vol-Vl; New Delhi 2008

8. Singh D, Baghel US, Gautam A, Baghel DS, Yadav D, Malik J, Yadav R. The genus Anogeissus: a review on ethnopharmacology, phytochemistry and pharmacology. J Ethnopharmacol. 2016;194:30-56.

9. Samar R, Shrivastava PN, Jain M. Ethnobotanical study of traditional medicinal plants used by tribe of Guna district, Madhya Pradesh, India. Int J Curr Microbiol App Sci. 2015:4:466-71.

10. Arjariya A, Chaurasia K. Some medicinal plants among the tribes of Chhatarpur district (M.P.) India. Ecoprint An Int J Ecol. 2009;16:43-50

11. Jain A, Katewa SS, Galav PK, Sharma P. Medicinal plant diversity of Sitamata wildlife sanctuary, Rajasthan, India. J Ethnopharmacol. 2005;102:143-57.

12. Bala LD, Singh R. Traditional use of herbal medicines against Rheumatism by the Tribals of Satna District (M.P.). Intl J Sci Res. 2013;4:1259-64.

13. Bala LD, Singh R. Ethnobotanical study of traditional medicinal plants used by Mawasi tribe of Chitrakoot region Distt. Satna (M.P.) India. Int J Biol Res. 2016;1:13-5

14. Jain SP, Singh SC, Srivastava S, Singh J, Mishra NP, Prakash A. Hitherto unreported ethnomedicinal uses of plants of Betul district of Madhya Pradesh. Indian J Trad Knowl. 2010;9:522-5.

15. Patil MV, Patil DA. Ethnomedicinal practices of Nasik District, Maharashtra. Indian J Trad Knowl. 2005:4:287-90

16. Reddy KK, Rajadurai S, Sastry KNS, Nayudamma Y. Studies on dhava tannins. I. Dhava tannins. The isolation and constitution of a gallotannin from dhava (Anogeissus latifolia). Aust J Chem. 1964;17:238-45.

17. Deshpande VH, Patil AD, Rama Rao AV, Venkatraman K. 3, 3'-Di-O-methy ellagic acid-4'- $\beta$-D-Xyloside and 3, 4, 3'-tri-O-methylflavellagic acid-4'- $\beta$ Dglucoside from the Anogeissus latifolia bark. Indian J Chem. 1976;14:641-3.

18. Rahman MS, Rahman MZ, Ahad Uddin ABM, Rashid MA. Steriod and triterpenoid from Anogeissus latifolia. Dhaka Univ J Pharm Sci. 2007:6:47-50.

19. Khandelwal KR. Practical Pharmacognosy. 15th ed. Pune: Nirali Prakashan; 2006. p. 149-56.

20. Dey YN, Sharma G, Wanjari MM, Kumar D, Lomash V, Jadhav AD. Curative effect of Amorphophallus paeoniifolius tuber on experimental hemorrhoids in rats. J Ethnopharmacol. 2016;192:183-91.

21. Patel RK, Patel VR, Patel MG. Development and validation of a RP-HPLC method for the simultaneous determination of embelin, rottlerin and ellagic acid in vidangadi churna. J Pharm Anal. 2012;2:366-71.

22. Organization for Economic Cooperation and Development (OECD), Guideline for the testing of chemicals., 2001. Revised draft guideline 423 Document on acute oral toxicity and acute toxicity class method. Available from: http://www.oecd.org. Cited 2013 Jun 21

23. Dey YN, Wanjari MM, Kumar D, Lomash V, Gaidhani SN, Jadhav AD. Oral toxicity of elephant foot yam (Amorphophallus paeoniifolius) tuber in mice. J Pharm Pharmacog Res. 2017:5(1):55-68.

24. Dey YN, Mahor S, Kumar D, Wanjari M, Gaidhani S, Jadhav A. Gastrokinetic activity of Amorphophallus paeoniifolius tuber in rats. J Intercult Ethnopharmacol. 2015;5(1):36-42.
25. Wu Y, Zhou C, Li X, Song L, Wu X, Lin W, Chen H, Bai H, Zhao J, Zhang R, Sun $\mathrm{H}$, Zhao $\mathrm{Y}$. Evaluation of anti-inflammatory activity of the total flavonoids of Laggera pterodonta on acute and chronic inflammation models. Phytother Res. 2006;20:585-90.

26. Dubuisson D, Dennis SG. The formalin test: a quantitative study of the analgesic effects of morphine, meperidine and brain stem stimulation in rats and cats. Pain. 1977;4:161-74.

27. Winter CA, Risley EA, Nuss GW. Carrageenan-induced oedema in hind paw of the rat as an assay for anti-inflammatory drugs. Proc Soc Exp Biol Med. 1962:111:544-7

28. Jain NK, Patil CS, Singh A, Kulkarni SK. A simple technique to evaluate inflammatory pain along with anti- inflammatory studies in carrageenaninduced paw edema. Indian J Pharmacol. 2001;33:114-5.

29. Tomazetti J, Avila DS, Ferreira APO, Martins JS, Souza FR, Royer C, Rubin MA, Oliveira MR, Bonacorso HG, Martins MA, Zanatta N, Mello CF. Baker yeast-induced fever in young rats: characterization and validation of an animal model for antipyretics screening. J Neurosci Methods. 2005;147: 29-35.

30. Shulan S, Wang T, Duan JA, Zhou W, Hua YQ, Tang YP, Yu L, Qian DW. Antiinflammatory and analgesic activity of different extracts of Commiphora myrrh. J Ethnopharmacol. 2011:134:251-8.

31. Coelho LP, Reis PA, de Castro FL, Gayer CRM, da Silva Lopes C, da Costa e Silva MC, de Carvalho Sabino KC, Todeschini AR, Coelho MG Antinociceptive properties of ethanolic extract and fractions of Pterodon pubescens Benth. seeds. J Ethnopharmacol. 2005;98:109-16.

32. Hunskaar S, Hole K. The formalin test in mice: dissociation between inflammatory and non-inflammatory pain. Pain. 1987;30:103-14.

33. Elisabetsky $E$, Amador TA, Albuquerque RR, Nunes DS, Carvalho ACT. Analgesic activities of Psychotria colorate (wild ex R. and S). Muel alkaloids. J Ethnopharmacol. 1995:48:77-83.

34. Imam MZ, Nahar N, Akter S, Rana MS. Antinociceptive activity of methanol extract of flowers of Impatiens balsamina. J Ethnopharmacol. 2012;142:80210

35. Tjolsen A, Berge OG, Hunskaar S, Rosland JH, Hole K. The formalin test: an evaluation of method. Pain. 1992;51:5-17.

36. Nantel F, Denis D, Gordon R, Northey A, Cirino M, Metters KM, Chan CC. Distribution and regulation of cyclooxygenase-2 in carrageenan-induced inflammation. Br J Pharmacol. 1999:128:853-9.

37. Handy RL, Moore PK. A comparison of the effects of L-NAME, 7-NI and L-NIL on carrageenan induced hindpaw oedema and NOS activity. Br J Pharmacol. 1998;123:1119-26.

38. Knight PR, Tait AR. Immunological aspects of anesthesia in: Prys-Roberts C, Brown BR, eds. International practice of anesthesia. Oxford: ButterworthHeinemann; 1996

39. Fantone JC, Ward PA. Role of oxygen-derived free radicals and metabolites in leukocyte-dependent inflammatory reactions. Am J Pathol. 1982;107:395418.

40. Agnihotri V, Karchuli MS, Varandani D, Koka S. Anti-inflammatory potential of Anogeissus latifolia: assessment through effect on oxidative stress, IL-6 and TNF-? Level. Inventi Impact Ethnopharmacol. 2015;2015(3):80-4.

41. Aronoff DM, Neilson EG. Antipyretics: mechanisms of action and clinical use in fever suppression. Am J Med. 2001;111:304-15.

42. Walter EJ, Hanna-Jumma S, Carraretto M, Forni L. The pathophysiological basis and consequences of fever. Crit Care. 2016;20:200.

43. Kaufmann WE, Andreasson Kl, Isakson PC, Worley PF. Cyclooxygenases and the central nervous system. Prostaglandins. 1997;54:601-24.

44. Chan $\mathrm{GHH}$, Fiscus R. Exaggerated production of nitric oxide (NO) and increases in inducible NO-synthase mRNA leves induced by the proinflammatory cytokine interleukin-1 $\beta$ in vascular smooth muscle cells of elderly rats. Exp Gerontol. 2004:39:384-94.

45. Corbett S, Daniel J, Drayton R, Field M, Steinhardt R, Garrett N. Evaluation of the anti-inflammatory effects of ellagic acid. J Perianesth Nurs. 2010;25:214-20.

46. Pradeep HA, Khan S, Ravikumar K, Ahmed MF, Rao MS, Kiranmai M, Reddy DS, Ahamed SR, Ibrahim M. Hepatoprotective evaluation of Anogeissus latifolia: in vitro and in vivo studies. World J Gastroenterol. 2009:1:4816-22.

47. Valério DA, Georgetti SR, Magro DA, Casagrande R, Cunha TM, Vicentini FT, Vieira SM, Fonseca MJ, Ferreira SH, Cunha FQ, Verri WA Jr. Quercetin reduces inflammatory pain: inhibition of oxidative stress and cytokine production. J Nat Prod. 2009:72(11):1975-9. https://doi.org/10.1021/ np900259y. 
48. Guardia T, Rotelli AE, Juarez AO, Pelzer LE. Anti-inflammatory properties of plant flavonoids. Effects of rutin, quercetin and hesperidin on adjuvant arthritis in rat. Farmaco. 2001;56(9):683-7.

49. Rogelio PP, Gabriela FM, Celia RL, Brígida HL, Isabel CH, Osiris MS, José AMG, Isela AG, Eduardo MB. Evaluation of the anti-inflammatory capacity of betasitosterol in rodent assays. Afr J Tradit Complement Altern Med. 2017;14(1): 123-30.

50. Khan MA, Rahman AA, Nahar L, Islam MB, Alam AHMK. In vivo analgesic and CNS depressant activities of antioxidative stem bark fraction of Morus alba $\mathrm{L}$. Dhaka Univ J Pharm Sci. 2014;13(2):225-7.

\section{Publisher's Note}

Springer Nature remains neutral with regard to jurisdictional claims in published maps and institutional affiliations.

\section{Submit your manuscript to a SpringerOpen ${ }^{\circ}$ journal and benefit from:}

- Convenient online submission

- Rigorous peer review

- Open access: articles freely available online

- High visibility within the field

- Retaining the copyright to your article

Submit your next manuscript at $\boldsymbol{\nabla}$ springeropen.com 